\title{
A Research on Designer Roles in Industries
}

\section{Eroglu, Ilgim ${ }^{\text {a }}$ E Esen, Ozge Ceylan ${ }^{\mathrm{b}}$}

${ }^{a} \mathrm{PhD}$ candidate at Mimar Sinan Fine Arts University, Turkey.

${ }^{\mathrm{b}} \mathrm{PhD}$ candidate at Mimar Sinan Fine Arts University, Turkey.

\begin{abstract}
In this study, possible differences for roles of designers in different industry systems were explored. It was studied if expectancies from designers change according to industries they work. This study is linked with a prior study which has investigated general expectancies from designers to get a hint about their work environment.

In a prior study done by the authors, it was investigated if concepts such as design thinking had any effect on requirements from designers. Since design thinking advocates designers to take active roles in managerial issues, and also require them to work with consumers as a team, it was hypothesized that recent job announcements may require capabilities related with these concepts. Also, when recent studies are evaluated, it can be seen that designers may take several different roles in companies. Therefore, it was investigated if capabilities referred in job announcements hinted any of the designer roles. It was found that companies asked for skills that addressed capabilities for designer roles such as team manager and process managers. However, the effects of industries' differing environments on requirements were not explored.

In the scope of this study, it was aimed to interview representatives from different industries to understand how different business systems affect design, and how designers transform themselves for different roles. Therefore, how business dimension along with type of products and services a company provides affect and change roles and requirements from designers was studied. A total of 50 companies were studied; 10 companies from 5 different industries with diverse characters were briefly interviewed to understand industry effect on requirements from designers. Interviews were thematically coded to define capabilities each company required. Industries included were shoes \& bags, furniture accessories, jewellery, packaging and advertising \& exhibition. It was found that requirements from designers differed according to the industry a company operates. Companies seem to emphasize different skills in relation with their business systems.
\end{abstract}

Keywords: Design management, design thinking, designer roles 


\section{Introduction}

Recent studies suggest that designers get more involved with managerial issues and designers' capabilities are adapted to decision making processes, therefore organizations encourage their managerial staff to develop designers' skills. (Cooper et. al., 2009). This trend can be evaluated together with design thinking, which also hints that both managerial problem solving and design problem solving processes are "wicked" by nature, and the capabilities needed to manage them are alike (Dorst, 2011).

In this study, design thinking concept and its' relevance to demanded designer skills according to industries will be explored through interviews. Former data gathered from job announcements will also be shared. The role of the designers in the organizations will be analized through required characteristics that are not strictly linked with design action.

\section{Design Thinking Concept and Roles of Designers in Organizations}

Design thinking suggests that designers' problem solving abilities has a function in business environment. Design thinking concept also supports the idea of designerly problem solving being used along with user oriented competition strategies (Brown, 2008). Hobday et. al. (2011) also state in their studies that “...the treatment of design as a human-centered, core creative activity in business challenges the overly scientific, rational view of the firm and, with it, many of the standard intervention tools of innovation management.". They hint that design's solution oriented approach does not resemble other humancentered approaches; business, society and economy can benefit from design thinking (Hobday et. al, 2012).

Researches on designers' abilities also provide insights about designers' capability to carry out various problem solving techniques. Dorst (2003) suggests that designers work with three types of problems; defined, underdefined and undefined. Defined problems mostly deal with objective issues, while undefined problems are generally subjectively solved by designers' own taste and talent; however underdetermined problems, which forms the majority of the problems in a design process, are mostly formed during design process and designer deals with these problems by considering possible problems and solutions (Dorst, 2003). The concept on underdefined and undefined problems seems to suit with Cross (1990, 2001), who supports the idea that dealing with uncertain situations is involved in design problems. Cross (1990) also declared that designers can (1) create unique and unusual solutions, (2) work with incomplete data (3) work with uncertainty, (4) solve practical problems by using their imagination (5) solve problems by using drawings and other visualization equipments. This statement is also compatible with the others suggesting that design mainly deals with "wicked problems" that are difficult to define (Rittel \& Weber,1973; Buchanan, 1992).

Studies on different designer roles may indicate that designers' abilities on problem solving can lead them to have more involvement with other functions in the organizations' environment. Valtonen (2005) argues that while designers have always worked in product development process, they increased their role in the area and business in general. In her study on how designers' role evolved in Finland, one of the designsolution providers she quoted declares that the corporate directors say they need to change companies' strategies; but they don't know why and how, and design-service providers deals with these situations (Valtonen, 2005). This statement briefly expresses the way design is implemented to companies' strategies to create value. It may also suggest that the designers' capabilities about dealing with unclear problems can help executives to clarify strategies. 
Another study on designers' roles in organizations defines three different roles a designer may take in a company (Perks et. al., 2005). Referred study mainly categorizes these three roles as shown below.

Table 1. Design roles and their descriptions, derived from Perks et. al. (2005) study.

\begin{tabular}{|c|c|c|}
\hline Design Role & Main Actions & Required Skills in General \\
\hline Design as Functional Specialism & $\begin{array}{c}\text { They concentrate purely on } \\
\text { design are evaluated as } \\
\text { resource }\end{array}$ & $\begin{array}{c}\text { Traditional skills (aesthetics, } \\
\text { visualization, } \\
\text { technical skills, etc) }\end{array}$ \\
\hline Design as Part of Multifunctional & $\begin{array}{c}\text { Generate interaction between } \\
\text { team-members, being a key } \\
\text { member in a team }\end{array}$ & $\begin{array}{c}\text { Skills to enable interaction and } \\
\text { communication, flexibility and team } \\
\text { building }\end{array}$ \\
\hline Designer as NPD Process Leader & $\begin{array}{c}\text { Getting more involved with } \\
\text { marketing studies to set the } \\
\text { direction, managing new product } \\
\text { development process and } \\
\text { informing other functions. }\end{array}$ & $\begin{array}{c}\text { Non-functional skills such as business } \\
\text { malysis, research, project management, } \\
\text { motivating others, communication } \\
\text { skills. }\end{array}$ \\
\hline
\end{tabular}

"Design as a part of multifunctional team" and "design as a NPD process leader", may express the design thinking effect on designers' roles. Team-building skills and overall process management skills are compatible with the suggestions that design supports product development process through designerly thinking and designers' familiarity with wicked problem concept may help them when they deal with process related issues.

In this study, the qualities that are not directly linked with core design abilities will be coded. Therefore, the roles and requirements other than main design function practice were tried to be identified.

\section{The Research}

In a prior study job opportunities announced in Coroflot website job board was read and coded and evaluated. The results for the codes in the prior study are explained below. Afterwards, the probable differences for different industries will be evaluated by the current study.

\subsection{Results of the Prior Study}

During the prior research, behavioral qualities and expectations were coded into groups listed and described as below (Authors, 2015).

- Working in teams/cross-functional teams stands for employer expecting designers to work with teams. "Cross-functional teams" and "teams" were not coded separately as it is not clear in most of the jobs if the word "team" refers to a cross-functional team or a monofunctional team. So, the base for the code was being able to function as a team in a design environment. 
- Working independently/self-manage/self-motivated refers to the ability of managing own work, without constant instruction and direction from a manager.

- Working closely with executives hints being able to work directly with executive staff.

- $\quad$ Mentoring/leadership implies to the ability of mentoring colleagues.

- $\quad$ Marketing research means doing marketing research activities.

- $\quad$ Brand management skills indicates the ability to build and/or manage a brand. Brand identity application abilities (to the product and services) are not included in this category.

- $\quad$ Business management skills refers to being able to handle managerial issues; dealing with subcontractors, accounting issues, etc.

- Multi-tasking/flexibility hints the qualifications required for handling multiple projects at the same time and switching projects when needed.

- Working in a fast paced environment implies ability to work with tight deadlines.

- $\quad$ Project management and organizational skills means being able to keep up with and direct a project within defined timetables and budgets.

- $\quad$ Working under pressure refers to being able to handle stress in daily work environment.

- $\quad$ Self starter/proactive indicates abilities for acting entrepreneurial and innovative without being told; being able to take initiative.

- $\quad$ Problem solving points out ability to deal with process oriented problems at work. Design related problem solving skills were not included in this code.

- $\quad$ Client interaction/management means being able to handle client accounts, presenting to and meeting with customers directly.

- $\quad$ Communication skills indicates having positive interpersonal skills and handling process related communication issues in a constructive way. Design related communication skills such as visual and verbal presentation skills are not included in this category.

When the job announcements in Coroflot website was coded; the frequencies for the codes given were derived as follows. 
Table 2 Derived from the prior study by writers. (Authors, 2015)

\begin{tabular}{|c|c|c|c|c|c|}
\hline Category & $\begin{array}{l}\text { Managerial } \\
\text { (out of 228) }\end{array}$ & $\begin{array}{c}\text { Senior } \\
\text { (out of 243) }\end{array}$ & $\begin{array}{c}\text { Regular } \\
\text { (out of 912) }\end{array}$ & $\begin{array}{c}\text { Intern } \\
\text { (out of 43) }\end{array}$ & $\begin{array}{l}\text { Total } \\
\text { (out of } \\
1430 \text { ) }\end{array}$ \\
\hline $\begin{array}{l}\text { Working in teams/cross- } \\
\text { functional teams }\end{array}$ & $172(75 \%)$ & $190(78 \%)$ & $610(\% 62)$ & $22(51 \%)$ & $994(69 \%)$ \\
\hline $\begin{array}{l}\text { Working independently/self- } \\
\text { manage/self-motivated }\end{array}$ & $41(17 \%)$ & $52(21 \%)$ & $242(27 \%)$ & $16(37 \%)$ & $351(25 \%)$ \\
\hline Working closely with executives & $13(5,6 \%)$ & $10(4,1 \%)$ & $31(3,3 \%)$ & $2(4,6 \%)$ & $56(3,9 \%)$ \\
\hline Mentoring/ leadership & $111(48 \%)$ & $70(29 \%)$ & $65(7,1 \%)$ & $0(0 \%)$ & $246(17 \%)$ \\
\hline Marketing research & $22(9,6 \%)$ & $22(9 \%)$ & $62(6,7 \%)$ & $3(6,9 \%)$ & $109(7,6 \%)$ \\
\hline Brand management skills & $33(14 \%)$ & $23(9,4 \%)$ & $46(5 \%)$ & $1(2,3 \%)$ & $103(7,1 \%)$ \\
\hline Business management skills & $45(20 \%)$ & $22(9 \%)$ & $46(5 \%)$ & $0(0 \%)$ & $113(7,8 \%)$ \\
\hline Multi-tasking/flexibility & $52(23 \%)$ & $57(24 \%)$ & $208(23 \%)$ & $8(19 \%)$ & $325(23 \%)$ \\
\hline $\begin{array}{c}\text { Working in a fast paced } \\
\text { environment }\end{array}$ & $56(24 \%)$ & $67(28 \%)$ & $265(29 \%)$ & $13(30 \%)$ & $401(28 \%)$ \\
\hline $\begin{array}{l}\text { Project management and } \\
\text { organizational skills }\end{array}$ & $169(73 \%)$ & $133(55 \%)$ & $450(49 \%)$ & $12(28 \%)$ & $764(53 \%)$ \\
\hline Working under pressure & $13(5,6 \%)$ & $19(7,8 \%)$ & $48(5,2 \%)$ & $1(2,3 \%)$ & $81(5,6 \%)$ \\
\hline Self starter/proactive & $35(15 \%)$ & $40(16 \%)$ & $131(14 \%)$ & $8(19 \%)$ & $214(15 \%)$ \\
\hline Problem solving & $47(20 \%)$ & $53(22 \%)$ & $151(17 \%)$ & $5(12 \%)$ & $256(18 \%)$ \\
\hline Client interaction/ management & $77(33 \%)$ & $77(32 \%)$ & $152(17 \%)$ & $4(9,3 \%)$ & $310(22 \%)$ \\
\hline Communication skills & $135(59 \%)$ & $151(\% 62)$ & $448(49 \%)$ & $16(37 \%)$ & $750(52 \%)$ \\
\hline
\end{tabular}

When the results are evaluated together with Perks et. al.'s (2006) model, it can be seen that the most required qualifications fit for team leader and process manager roles. 
Table 3. Derived from the prior study by writers. (Authors, 2015)

\begin{tabular}{|c|c|c|}
\hline Groups & Qualifications and Total Frequencies & $\begin{array}{c}\text { Number of Announcements } \\
\text { That Require at Least One of } \\
\text { The Categories }\end{array}$ \\
\hline $\begin{array}{c}\text { Design as Part of Multifunctional } \\
\text { Team }\end{array}$ & $\begin{array}{l}\text { Working in teams/cross-functional teams - } \\
\qquad 69 \% \\
\text { Communication skills - } 52 \%\end{array}$ & $1179(82 \%)$ \\
\hline Design as NPD Process Leader & $\begin{array}{c}\text { Working closely with executives }-3,9 \% \\
\text { Mentoring/leadership - } 17 \% \\
\text { Marketing research - 7,6\% } \\
\text { Brand management skills - 7,1\% } \\
\text { Project management and organizational skills } \\
-53 \% \\
\text { Problem solving - } 18 \% \\
\text { Client interaction/management - } \% 22 \\
\text { Communication skills - } 52 \%\end{array}$ & $1169(82 \%)$ \\
\hline Designers' Working Environment & $\begin{array}{c}\text { Multi-tasking/flexibility - } 23 \% \\
\text { Working independently/ self-manage/self- } \\
\text { motivated - } 25 \% \\
\text { Working in a fast-paced environment - } 28 \% \\
\text { Working under pressure - } 5,6 \% \\
\text { Self-starter/proactive - } 15 \%\end{array}$ & $826(58 \%)$ \\
\hline
\end{tabular}

However, in this research, codes were not evaluated according to industries. Also the evidence about why organizations demanded these qualifications was limited.

\subsection{Research Method}

A total of 50 companies were interviewed in this study. Companies were chosen among 5 industries, each designing their own products. It was aimed to ask organizations their expectancies from designers, so each of these firms employ designers either regularly or project base. Therefore, purposive sampling was used as the sampling method (Robson, 2002).

Companies were interviewed mostly at industrial exhibitions; packaging industry at Avrasya Ambalaj 2015, furniture accessories at Intermob 2015, shoe \& bags at Aymod and jewellery at İstanbul Jewellery Show Ekim. Advertising \& exhibition industry was interviewed through e-mail. Due to the medium and environment, interviews were kept short and evolved around one single question. Duration was between 5-20 minutes; coding was done during interviews and notes were taken when necessary.

Initial question was "What are the qualifications you demand in a designer that you employ, other than the functional designer abilities?". Most of the respondents answered this question by basically explaining their work environments. Additional questions were asked when needed. 


\section{Results}

Results of the study will be evaluated by industries.

\subsection{Bags and Shoes Industry}

The codes for the shoe \& bags industry can be seen below.

Table 4. Codes for shoe $\&$ bags industry

\begin{tabular}{|c|c|c|c|c|c|c|c|c|c|c|c|}
\hline SHOE \& BAGS & C1 & $\mathrm{C} 2$ & $\mathbf{C 3}$ & $\mathrm{C} 4$ & C5 & C6 & C7 & $\mathrm{C} 8$ & C9 & C10 & Total \\
\hline $\begin{array}{l}\text { Working in teams/cross- } \\
\text { functional teams }\end{array}$ & $\mathrm{X}$ & & & & & $\mathrm{X}$ & & & $\mathrm{X}$ & & 3 \\
\hline $\begin{array}{l}\text { Working independently/self- } \\
\text { manage/self-motivated }\end{array}$ & & & & & & & & & & & 0 \\
\hline $\begin{array}{l}\text { Working closely with } \\
\text { executives }\end{array}$ & $\mathrm{X}$ & & $\mathrm{X}$ & & & & & & $\mathrm{X}$ & & 3 \\
\hline Mentoring/ leadership & & & & & & & $\mathrm{X}$ & & & & 1 \\
\hline Marketing research & $\mathrm{X}$ & $X$ & & & $\mathrm{X}$ & $\mathrm{X}$ & $\mathrm{X}$ & $\mathrm{X}$ & & $\mathrm{X}$ & 7 \\
\hline Brand management skills & & & & & & & & & & & 0 \\
\hline Business management skills & & & & & & & & & & & 0 \\
\hline Multi-tasking/flexibility & & & & & & & & & & & 0 \\
\hline $\begin{array}{c}\text { Working in a fast paced } \\
\text { environment }\end{array}$ & & & & & & & & & & & 0 \\
\hline $\begin{array}{l}\text { Project management and } \\
\text { organizational skills }\end{array}$ & & $\mathrm{X}$ & & $\mathrm{X}$ & & & $\mathrm{X}$ & $\mathrm{X}$ & $\mathrm{X}$ & $\mathrm{X}$ & 6 \\
\hline Working under pressure & & & & & & & & & & & 0 \\
\hline Self starter/proactive & & & & & & & & & & & 0 \\
\hline Problem solving & & & & $\mathrm{X}$ & & & & & & & 1 \\
\hline $\begin{array}{l}\text { Client interaction/ } \\
\text { management }\end{array}$ & & & & $\mathrm{X}$ & & & & & & & 1 \\
\hline Communication skills & & & & $\mathrm{X}$ & & & & $\mathrm{X}$ & & & 2 \\
\hline
\end{tabular}


Shoe \& bags organizations can be evaluated within fashion industry. They work on season base and produce their own products to be sold by retailers.

The top two codes for this industry is "project management and organizational" skills with $6 / 10$ frequency and "marketing research" with $7 / 10$ frequency. As the designs in this industry is strongly related with trends, companies mostly demand that designers do their own market research and bring their insights about fashion trends to the firm; so they require marketing research capability from a designer. Firms also mostly request project management and organizational skills but somewhat in a limited way. Companies demand designers to deal with design process by themselves, but only until model sketches are drawn.

"They should bring us many, many model drawings... tens of. The production is our task. I can produce what they draw, and even if 5 or 10 of them is sold in the market, their job is done" $\mathrm{C} 2$

Time and pace based requirements like working in a fast paced environment; multi tasking and working under pressure are not mentioned by interviewees. This may be because the industry's pace is already set by seasons and long term planning can be done.

One of the companies, C4, was mostly working with a boutique style, so required designers to bring alternative ideas to current trends. This included with working with customers for related projects, and effects can be seen on communication skills and problem solving skills requirements.

\subsection{Furniture Accessories Industry}

The codes for the furniture accessories (handles, wheels, foots, etc) industry are as follows:

Table 5. Codes for furniture accessories industry

\begin{tabular}{|c|l|l|l|l|l|l|l|l|l|l|l|}
\hline FURNITURE ACCESSORIES & C1 & C2 & C3 & C4 & C5 & C6 & C7 & C8 & C9 & C10 & Total \\
\hline $\begin{array}{c}\text { Working in teams/cross- } \\
\text { functional teams }\end{array}$ & X & & X & X & X & & X & X & X & X & 8 \\
\hline $\begin{array}{c}\text { Working independently/ } \\
\text { self-manage/self-motivated }\end{array}$ & & & & & & & & & & & 0 \\
\hline Working closely with executives & & & & & & X & X & & X & & 3 \\
\hline Mentoring/ leadership & & & & & & X & & & & & 1 \\
\hline Marketing research & & & & & & & $X$ & $X$ & $X$ & & 3 \\
\hline $\begin{array}{c}\text { Brand management skills } \\
\text { Business management skills }\end{array}$ & & & & & & & & & & & 0 \\
\hline Multi-tasking/flexibility & & & & & $X$ & $X$ & & $X$ & $X$ & & 4 \\
\hline Working in a fast paced \\
environment
\end{tabular}




\begin{tabular}{|c|l|l|l|l|l|l|l|l|l|l|l|}
\hline $\begin{array}{c}\text { Project management and } \\
\text { organizational skills }\end{array}$ & $\mathrm{X}$ & $\mathrm{X}$ & $\mathrm{X}$ & $\mathrm{X}$ & $\mathrm{X}$ & $\mathrm{X}$ & $\mathrm{X}$ & $\mathrm{X}$ & $\mathrm{X}$ & $\mathrm{X}$ & 10 \\
\hline Working under pressure & & & & & & & & & & & 0 \\
\hline Self starter/proactive & & & & & & & & & & & 0 \\
\hline Problem solving & $\mathrm{X}$ & & & & & & & & & & 1 \\
\hline Client interaction/ management & & $\mathrm{X}$ & & $\mathrm{X}$ & & $\mathrm{X}$ & & $\mathrm{X}$ & $\mathrm{X}$ & $\mathrm{X}$ & 6 \\
\hline Communication skills & $\mathrm{X}$ & $\mathrm{X}$ & $\mathrm{X}$ & $\mathrm{X}$ & $\mathrm{X}$ & $\mathrm{X}$ & & $\mathrm{X}$ & $\mathrm{X}$ & $\mathrm{X}$ & 9 \\
\hline
\end{tabular}

The most required qualifications in furniture accessories industry are working in cross-functional teams with a frequency of 8 , project management skills with a frequency of 10 and communication skills with a frequency of 9 over 10 .

Furniture accessories industries have a mixed customer base, as they can both design products for a specific furniture producer or design their own products to be sold by retailers. As designers do not define qualifications of the products just by interpreting trends, qualifications for working with other counterparts were demanded, such as working with teams and client interaction skills (6/10). This also diminishes the request for marketing research skills, when compared to industries driven by fashion trends.

"Our marketing team deals with the needs of the customers. Designer just needs to turn them into products to be realized by our production team." $\mathrm{C} 5$

As sometimes designers have to work with their corporate customers' pace, multi tasking is required by some of the companies. But most of the companies declared that custom designs for other companies do not form the majority in their total design work, effects of this criterion is limited.

\subsection{Jewellery Industry}

The frequencies for the jewellery industry are as follows:

Table 6. Codes for jewellery industry

\begin{tabular}{|c|l|l|l|l|l|l|l|l|l|l|l|}
\hline JEWELLERY & C1 & C2 & C3 & C4 & C5 & C6 & C7 & C8 & C9 & C10 & Total \\
\hline $\begin{array}{c}\text { Working in teams/cross- } \\
\text { functional teams }\end{array}$ & & & & $X$ & $X$ & $X$ & & $X$ & & & 4 \\
\hline $\begin{array}{c}\text { Working independently/self- } \\
\text { manage/self-motivated }\end{array}$ & $\mathrm{X}$ & & $\mathrm{X}$ & & $\mathrm{X}$ & $\mathrm{X}$ & & & $\mathrm{X}$ & & 5 \\
\hline $\begin{array}{c}\text { Working closely with } \\
\text { executives }\end{array}$ & & & & & & & & & & & \\
\hline
\end{tabular}




\begin{tabular}{|c|l|l|l|l|l|l|l|l|l|l|l|}
\hline Mentoring/ leadership & & & & & & & & & & & 0 \\
\hline Marketing research & $\mathrm{X}$ & $\mathrm{X}$ & & & $\mathrm{X}$ & & & $\mathrm{X}$ & $\mathrm{X}$ & $\mathrm{X}$ & 6 \\
\hline Brand management skills & & & & & & & & & & & 0 \\
\hline Business management skills & & $\mathrm{X}$ & & $\mathrm{X}$ & $\mathrm{X}$ & $\mathrm{X}$ & & & & $\mathrm{X}$ & 5 \\
\hline $\begin{array}{c}\text { Multi-tasking/flexibility } \\
\text { Working in a fast paced } \\
\text { environment }\end{array}$ & & & & & & & & & & & 0 \\
\hline $\begin{array}{c}\text { Project management and } \\
\text { organizational skills }\end{array}$ & $\mathrm{X}$ & $\mathrm{X}$ & $\mathrm{X}$ & $\mathrm{X}$ & $\mathrm{X}$ & $\mathrm{X}$ & $\mathrm{X}$ & $\mathrm{X}$ & $\mathrm{X}$ & $\mathrm{X}$ & 10 \\
\hline $\begin{array}{c}\text { Working under pressure } \\
\text { melf starter/proactive }\end{array}$ & & $\mathrm{X}$ & & $\mathrm{X}$ & & & & $\mathrm{X}$ & & $\mathrm{X}$ & 4 \\
\hline Problem solving & & $\mathrm{X}$ & & $\mathrm{X}$ & & & & & & & 2 \\
\hline $\begin{array}{c}\text { Client interaction/ } \\
\text { management }\end{array}$ & $\mathrm{X}$ & $\mathrm{X}$ & & $\mathrm{X}$ & & & & $\mathrm{X}$ & & & 4 \\
\hline
\end{tabular}

Jewellery industry resembles shoe \& bags industry, as it is related to trends; they also both work with end users and retailers. However, since the materials used in the sector are quite expensive and amount of material used is very decisive in the final price of the product, designers have a closer link with production teams and customers.

The most required three qualifications in jewellery sector are marketing research with a frequency of 6 , project management skills with a frequency of 10 and communication skills with a frequency of 8 .

Similar to bags \& accessories sector, marketing research and project management skills are two of the most demanded qualifications. However, especially when designing boutique products for exclusive customers, designers get in contact with end users or retailers.

"It is designers' job to get in contact with customers.. We expect designers to follow market and add their insights to products." C9

Since the industry works with a seasonal pace, just like shoe \& bags industry, schedule is not tight. Therefore qualifications addressing adapting to tight schedule are not frequently requested. However, producers require designers to take more initiative by demanding them to get more involved with business management aspects, work with executives and be a self starter, when compared to shoe \& bags industry.

\subsection{Packaging Industry}

The requested qualifications for the packaging industry can be seen in the table below. 
Table 7. Codes for packaging industry

\begin{tabular}{|c|c|c|c|c|c|c|c|c|c|c|c|}
\hline PACKAGING & C1 & $\mathrm{C} 2$ & $\mathbf{C 3}$ & $\mathrm{C} 4$ & C5 & C6 & $\mathrm{C} 7$ & $\mathbf{C 8}$ & C9 & C10 & Total \\
\hline $\begin{array}{l}\text { Working in teams/cross- } \\
\text { functional teams }\end{array}$ & & $\mathrm{X}$ & & $\mathrm{X}$ & & $\mathrm{X}$ & $\mathrm{X}$ & $\mathrm{X}$ & & & 5 \\
\hline $\begin{array}{l}\text { Working independently/self- } \\
\text { manage/self-motivated }\end{array}$ & $\mathrm{X}$ & & $\mathrm{X}$ & $\mathrm{X}$ & & & & & $\mathrm{X}$ & & 4 \\
\hline Working closely with executives & $\mathrm{X}$ & $\mathrm{X}$ & & $\mathrm{X}$ & & & $\mathrm{X}$ & & & & 4 \\
\hline Mentoring/ leadership & $\mathrm{X}$ & & & & & & & & & & 1 \\
\hline Marketing research & $\mathrm{X}$ & $\mathrm{X}$ & & & & & & $\mathrm{X}$ & & $\mathrm{X}$ & 4 \\
\hline \multicolumn{12}{|l|}{ Brand management skills } \\
\hline Business management skills & $\mathrm{X}$ & & & & & $\mathrm{X}$ & & & & & 2 \\
\hline Multi-tasking/flexibility & & & & & & & & $\mathrm{X}$ & & $\mathrm{X}$ & 2 \\
\hline $\begin{array}{l}\text { Working in a fast paced } \\
\text { environment }\end{array}$ & & & & $\mathrm{X}$ & $\mathrm{X}$ & $\mathrm{X}$ & & $\mathrm{X}$ & & & 4 \\
\hline $\begin{array}{l}\text { Project management and } \\
\text { organizational skills }\end{array}$ & $\mathrm{X}$ & & $\mathrm{X}$ & $\mathrm{X}$ & & $\mathrm{X}$ & $\mathrm{X}$ & $\mathrm{X}$ & & $\mathrm{X}$ & 7 \\
\hline Working under pressure & & & & & & $X$ & & $X$ & $X$ & & 3 \\
\hline Self starter/proactive & & & & & $\mathrm{X}$ & & & & & & 1 \\
\hline Problem solving & $\mathrm{X}$ & & $\mathrm{X}$ & & & $\mathrm{X}$ & $\mathrm{X}$ & & & $\mathrm{X}$ & 5 \\
\hline Client interaction/management & $\mathrm{X}$ & $\mathrm{X}$ & & $\mathrm{X}$ & & $\mathrm{X}$ & $\mathrm{X}$ & & $\mathrm{X}$ & & 6 \\
\hline Communication skills & $\mathrm{X}$ & $\mathrm{X}$ & $X$ & $\mathrm{X}$ & & & $X$ & $\mathrm{X}$ & & $\mathrm{X}$ & 7 \\
\hline
\end{tabular}

Packaging industry is strongly defined by corporate customers' demands. Companies work with defined demands by customers, and pace of the organizations fluctuates according to demands from the market. Unlike furniture accessories industry, companies almost always act according to demands; project periods are shorter and production quantities are higher.

The most asked qualifications are mentioned by slightly more than half of the organizations interviewed; project management skills has a frequency of 7, client interaction and management have a frequency of 6 , while communication skills is mentioned by 7 companies. Also, problem solving skills and working with teams were hinted by half of the companies.

Time constraints are one of the major factors that affect expectations of companies from designers. Some of the companies mentioned existence of pressure in the work environment and multitasking as factors designers should deal with. Also client interaction skills is requested both for more accurate outcomes and 
to manage time constraints.

"They should be able to communicate with customers... Because we don't have time for it." C4

Unlike other sectors, packaging firms demand their designers to expand their process management skills to production process.

"The top agencies in the industry do not deal with production. However we are more like an overall service provider, so our designers have to deal with production also." C6

\subsection{Advertising and Exhibition Industry}

The codes for the advertising and exhibition (fair stands, product stands, etc.) industry is as follows:

Table 7 Codes for advertising and exhibition industry

\begin{tabular}{|c|c|c|c|c|c|c|c|c|c|c|c|}
\hline ADVERTISING AND EXHIBITION & C1 & $\mathrm{C} 2$ & $\mathrm{C3}$ & $\mathrm{C} 4$ & C5 & C6 & $\mathrm{C} 7$ & $\mathrm{C8}$ & C9 & $\mathrm{C} 10$ & Total \\
\hline $\begin{array}{c}\text { Working in teams/cross-functional } \\
\text { teams }\end{array}$ & $\mathrm{X}$ & $\mathrm{X}$ & $\mathrm{X}$ & $\mathrm{X}$ & & & & $\mathrm{X}$ & & $\mathrm{X}$ & 6 \\
\hline $\begin{array}{l}\text { Working Independently/ } \\
\text { self-manage/self-motivated }\end{array}$ & $X$ & & & & & & & & $\mathrm{X}$ & & 2 \\
\hline Working closely with executives & $\mathrm{X}$ & $\mathrm{X}$ & $\mathrm{X}$ & $\mathrm{X}$ & & & & & $\mathrm{X}$ & & 5 \\
\hline Mentoring/ leadership & $\mathrm{X}$ & & & & & & & & $\mathrm{X}$ & & 2 \\
\hline Marketing research & $\mathrm{X}$ & $\mathrm{X}$ & $\mathrm{X}$ & $\mathrm{X}$ & & & & & $\mathrm{X}$ & & 5 \\
\hline Brand management skills & & & & & & & & & & & 0 \\
\hline Business management skills & $\mathrm{X}$ & $\mathrm{X}$ & & & & & & & $\mathrm{X}$ & & 3 \\
\hline Multi-tasking/flexibility & $\mathrm{X}$ & $\mathrm{X}$ & & $\mathrm{X}$ & $\mathrm{X}$ & $\mathrm{X}$ & $\mathrm{X}$ & $\mathrm{X}$ & $\mathrm{X}$ & $\mathrm{X}$ & 9 \\
\hline Working in a fast paced environment & $\mathrm{X}$ & $\mathrm{X}$ & $\mathrm{X}$ & $\mathrm{X}$ & $\mathrm{X}$ & $\mathrm{X}$ & $\mathrm{X}$ & $\mathrm{X}$ & $\mathrm{X}$ & & 9 \\
\hline $\begin{array}{l}\text { Project management and organizational } \\
\text { skills }\end{array}$ & $\mathrm{X}$ & $\mathrm{x}$ & $\mathrm{x}$ & $\mathrm{x}$ & $\mathrm{X}$ & $\mathrm{X}$ & $\mathrm{X}$ & $\mathrm{X}$ & $\mathrm{X}$ & $\mathrm{X}$ & 10 \\
\hline Working under pressure & $\mathrm{X}$ & $\mathrm{X}$ & & $\mathrm{X}$ & & & & & & & 3 \\
\hline Self starter/proactive & $\mathrm{X}$ & $\mathrm{X}$ & & & & & & & $\mathrm{X}$ & & 3 \\
\hline Problem solving & $\mathrm{X}$ & $\mathrm{X}$ & $\mathrm{X}$ & $\mathrm{X}$ & $\mathrm{X}$ & $\mathrm{X}$ & $\mathrm{X}$ & $\mathrm{X}$ & $\mathrm{X}$ & $\mathrm{X}$ & 10 \\
\hline Client interaction/management & $\mathrm{X}$ & $\mathrm{X}$ & $\mathrm{X}$ & $\mathrm{X}$ & $\mathrm{X}$ & $\mathrm{X}$ & $\mathrm{X}$ & $\mathrm{X}$ & $\mathrm{X}$ & & 9 \\
\hline Communication skills & $\mathrm{X}$ & $\mathrm{X}$ & $\mathrm{X}$ & $X$ & & & & & $\mathrm{X}$ & & 5 \\
\hline
\end{tabular}


Advertising and exhibition sector is also strictly constrained with corporate customer demands and time tables. Unlike other industries, some of the products such as fair stands can be custom produced for once according to the stand area and budget. Workload also fluctuates according to customer demands.

Six of the mentioned codes were requested by more than half of the companies. Problem solving skills and project management skills are demanded by all of the companies, while 9 of the interviewed organizations also demanded multi tasking and flexibility, working in a fast paced environment, client interaction and management. Ability to work in teams was also mentioned in 6 interviews. Communication skills, working closely with executives and marketing research have moderate frequency, while business management, working under pressure and being a self-starter were mentioned just below the average frequency.

“...we prefer face to face communication, rarely a project may be given through e-mail. We care for a continuous communication" $\mathrm{C} 2$

"When needed, brainstorming is done with chiefs or executives by the relevant designer on the project or the design team." $\mathrm{C} 1$

"Being able to work with flexible work hours is required." C8

"Production pursuance is done when necessary" $\mathrm{C} 1$

From the codes and comments, it can be interpreted that companies mostly work with pace of the customers, therefore designers should be able to adapt to the conditions with minimum supervision. Also, designers get involved in a larger percent of total product development process, as they get involved in the process from customer brief to production stage.

\section{Conclusion and Further Studies}

When results of the current study are investigated, it may be suggested that requirements from designers can change according to industries they work. Therefore, a system effect in business dimension can be seen on roles that designers take.

Shoe \& bags and jewellery industries require more functional specialists more than other sectors. Marketing research and project management skills are required in more than half of the companies in both industries. Jewellery organizations also require communication skills, as designers have to work closer with marketing staff and production team; as the industry is more price and production sensitive than shoe \& bags industry. In these sectors companies' main expectation is to produce fashionable products, so they need to rely on designers' functional capabilities. Most of the time companies declare that they only request drawings from designers and they can go on with the rest of the process without the involvement of designer.

Furniture accessories sector has both own design production and custom design production for furniture firms. So this industry requires communication skills more than fashion related industries. Also companies require designers to be a team player, as production of furniture accessories is usually by molding and most of them go through a finishing process; unlike jewellery or shoes \& bags. Therefore companies require designers to get more involved with the production and marketing staff. The role that best suits to a designer in this industry could be designer as a part of a multifunctional team.

Packaging and advertising \& exhibition industries are more corporate customer related, so the work pace is mostly defined by customers. In the interviews, organizations declared that most of the time sales staff does not have the time for pursuing the complete product development process, therefore they demand 
that designers follow through this process. So, the qualifications they require are process management, communication skills, problem solving, being a team member and client interaction, hinting the role designer as NPD process leader.

Therefore, the systems that companies work within seem to effect requirements for designers. As a result, designers take different roles in companies according to business dimension. Designers seem to have managerial roles within industries that require working closely with customers on project bases. However, industries that can control their own pace that work on seasonal periods require functional skills more than managerial skills, as they rely heavily on designers' capabilities on perception of trends and fashion.

Due to the limited time and length of this study, 5 industries were studied through 50 firms. Research can be expended with more interviews or by coding more job announcements through different industries. Also, industries can be studied further in terms of work pace and environment in order to match qualifications better with related industries.

\section{References}

BROWN, T., 2008, “Design Thinking”, Harvard Business Review, June, 1-11.

BUCHANAN, R. 1992. "Wicked problems in design thinking". Design Issues. 8(2), 14-19.

COOPER, R., JUNGINGER, S., (2009), "The Evolution of Design Management”, Design Management Journal, 4 (1), 4-6.

COOPER, R., (2009), JUNGINGER, S., LOCKWOOD, T., "Design Thinking and Design Management: A Research and Practice Perspective"; Design Management Review; 20-2, 45-55.

CROSS, N. (1990). "The Nature and Nurture of Design Ability”. Design Studies. 11:3, 127-140.

CROSS, N. (2001). "Designerly ways of knowing: design discipline versus design science". Design Issues. 17:3, 4955.

DORST, K. (2003). "The Problem of Design Problems. Expertise in Design”. Design Thinking Research Symposium 6. 17-19 November. University of Technology, Sydney, Australia.

DORST, K., (2011), “The Core of Design Thinking and It’s Application”, Design Studies, 32, 521-532, 2011.

HOBDAY, M., BODDINGTON, A., GRAnTHAM, A. (2011). “An Innovation Perspective on Design: Part 1". Design Issues, 27:4, 5-15

HOBDAY, M., BODDINGTON, A., GRANTHAM, A. (2012). "An Innovation Perspective on Design: Part 2". Design Issues, 28:1, 18-29

PERKS, H., COOPER, R. JONES, C. (2005). "Characterizing the Role of Design in New Product Development: An Empirically Derived Taxonomy”. The Journal of Product Innovation Management. 22, 111-127.

RITTEL, H.W.J, and WEBBER, M.M. (1973). "Dilemmas in a general theory of planning”. Policy Sciences. 4,155169.

ROBSON, C. (2002). Real World Research: A Resource for Social Scientists and Practitioner, Blackwell Publishing, Cornwall.

VALTONEN, A. (2005). "Six Decades - and Six Different Roles for the Industrial Designer". Nordes Conference In the Making. 30-31 May, 2005. Copenhagen. 